\title{
Extant populations of endemic partulids on Tahiti, French Polynesia
}

\author{
Trevor Coote, Eric Loeve, Jean-Yves Meyer and Dave Clarke
}

\begin{abstract}
The current distribution of endemic partulid snails on Tahiti in French Polynesia reflects the danger of ignoring expert advice and introducing an alien species into a fragile island ecosystem. The endemic tree-snail fauna of the island now faces extinction. Although the extinction of the native species of Partula (Partulidae; Polynesian tree snails) on Moorea in French Polynesia is well known in the world of conservation biology, losses on other Pacific islands are less well described. This paper presents an update on the status of partulid snail populations on Tahiti in the light of
\end{abstract}

\section{Introduction and background}

When the giant African land snail Achatina fulica was introduced into French Polynesia as a food source in 1967, it escaped and bred so rapidly that it threatened the economy of the islands, destroying food crops and local garden flora (Pointier \& Blanc, 1985). The solution to the problem at that time was perceived by the local government authorities to be the introduction of a carnivorous snail, Euglandina rosea, a native of Florida, USA. Despite warnings from authorities on molluscan biology (J. B. Burch, pers. comm.), the introductions took place on Tahiti in 1975 and on Moorea in 1977.

The extinction of the seven endemic Moorean species of Partula tree snails, attributable to this introduction, is well documented (Clarke et al., 1984; Murray et al., 1988; Gould, 1991; Cowie, 1992), largely because of the extensive scientific research on the partulids of that island by evolutionary biologists (see especially Crampton, 1932; Johnson et al., 1993).

Trevor Coote (corresponding author) Institute of Zoology, Zoological Society of London, Regents Park, London NW1 4RY, UK.

Fax: + 44171586 2870; e-mail: t.coote@ioz.co.uk

Dave Clarke Invertebrate Conservation Unit, Zoological Society of London, Regents Park, London NW1 4RY, UK. Fax: + 44171722 5390; e-mail: dave.clarke@zsl.org

Eric Loeve BP 3577 Papeete, Tahiti, French Polynesia. Tel/Fax: + 6894265 61; e-mail: eric.loeve@iss.pf

Jean-Yves Meyer Délégation à la Recherche, BP 20981 Papeete, Tahiti, French Polynesia. Fax: +68943 34 00;

e-mail: Jean-Yves.Meyer@services.gov.pf

Received 2 February 1998. Accepted 2 December 1998 fieldwork undertaken between 1995 and 1997. Native snails still exist in good numbers in two areas, at opposite ends of the island. In other areas, sightings of single or a few individuals indicate remnant populations now on the edge of extinction. Efforts to protect these populations and others in French Polynesia are being planned in collaboration with local government authorities.

Keywords Biological control, conservation, Euglandina, Partula, Tahiti.

The situation in Tahiti has been less well documented. Tahiti is the largest $(1045 \mathrm{sq} \mathrm{km})$ and the highest $(2241 \mathrm{~m})$ island of the Society Island archipelago. It comprises Tahiti-Nui (large island) and Tahiti-Iti (small island) joined by an isthmus at Taravao (Fig. 1). Between 1975 and 1978 E. rosea was introduced into Tahiti at three localities: the Botanic Garden at Papeari (now the Jardin Botanique Harrison Smith); the Station de Recherche Agronomique at Papara; and on government (Service de l'Economie Rurale) land on the plateau at Taravao.

The taxonomy of Tahitian partulids was first described in detail by Hartman (1881), Garrett (1884) and Mayer (1902). Drawing on these studies, together with his extensive fieldwork, Crampton (1916) identified eight species of the genus Partula on Tahiti. In addition, he described a number of varieties of each, as well as eight subspecies of $P$. otaheitana. This taxonomy has subsequently been revised, most significantly by Kondo (1968), who, in addition, recognized one species of Samoana. Since then, there have been minor revisions to the taxonomy of both genera.

The partulid fauna of Tahiti have not been studied in as much detail as that of Moorea in recent years. Consequently, less notice was taken of the extinctions on Tahiti. In 1984, it was known that the area invaded by $E$. rosea extended from Papara on the south coast to Taravao (Murray et al., 1988).

\section{Surveys}

The situation on Moorea and Tahiti is part of a much wider problem for this family of snails because $E$. rosea has been introduced into many of the islands of the 
Pacific basin where partulids occur. The Partula Propagation Group was established in 1986 in response to this threatened extinction to co-ordinate the captive breeding of snails held in captivity at that time. To reflect the broader interests and activities of the group, it was renamed the Pacific Island Land Snail Group (PILSG) in 1994, as part of the IUCN Mollusc Specialist Group, and aims to conserve the family Partulidae, as well as other endemic snail families of the Pacific region, notably Achatinellidae (PearceKelly et al., 1994). In 1987, a survey by J. J. and E. Murray, supported by the Captive Breeding Specialist Group of the IUCN, reported only four taxa remaining ( $P$. otaheitana rubescens, $P$. affinis, $P$. hyalina and $P$. clara), with positive evidence of their existence only in Tiarei and Mahaena Valleys in the north-east. Partula had disappeared from the valleys of Pirae, Pape- hue and Tereehia (Murray et al., 1988). Since 1994 PILSG has conducted surveys in a number of valleys on Tahiti, as well as on six islands of the Marquesas archipelago.

By 1994, extrapolating from the situation on Moorea, it was assumed that all tree-snail species in Tahiti were extinct in the wild, and that only $P$. otaheitana, $P$. hyalina and $P$. nodosa remained extant in captive-breeding programmes (Pearce-Kelly et al., 1994). Samples taken by B. Clarke and J. J. Murray show that there were flourishing populations on Tahiti before the introduction of $E$. rosea and a decline soon after (J. J. Murray, pers. comm.). However, later that year, P. Pearce-Kelly (Zoological Society of London and PILSG) found a remnant population of $P$. otaheitana at $1400 \mathrm{~m}$, close to the TV antenna by the crest of Mt Marau (Plate 1), in

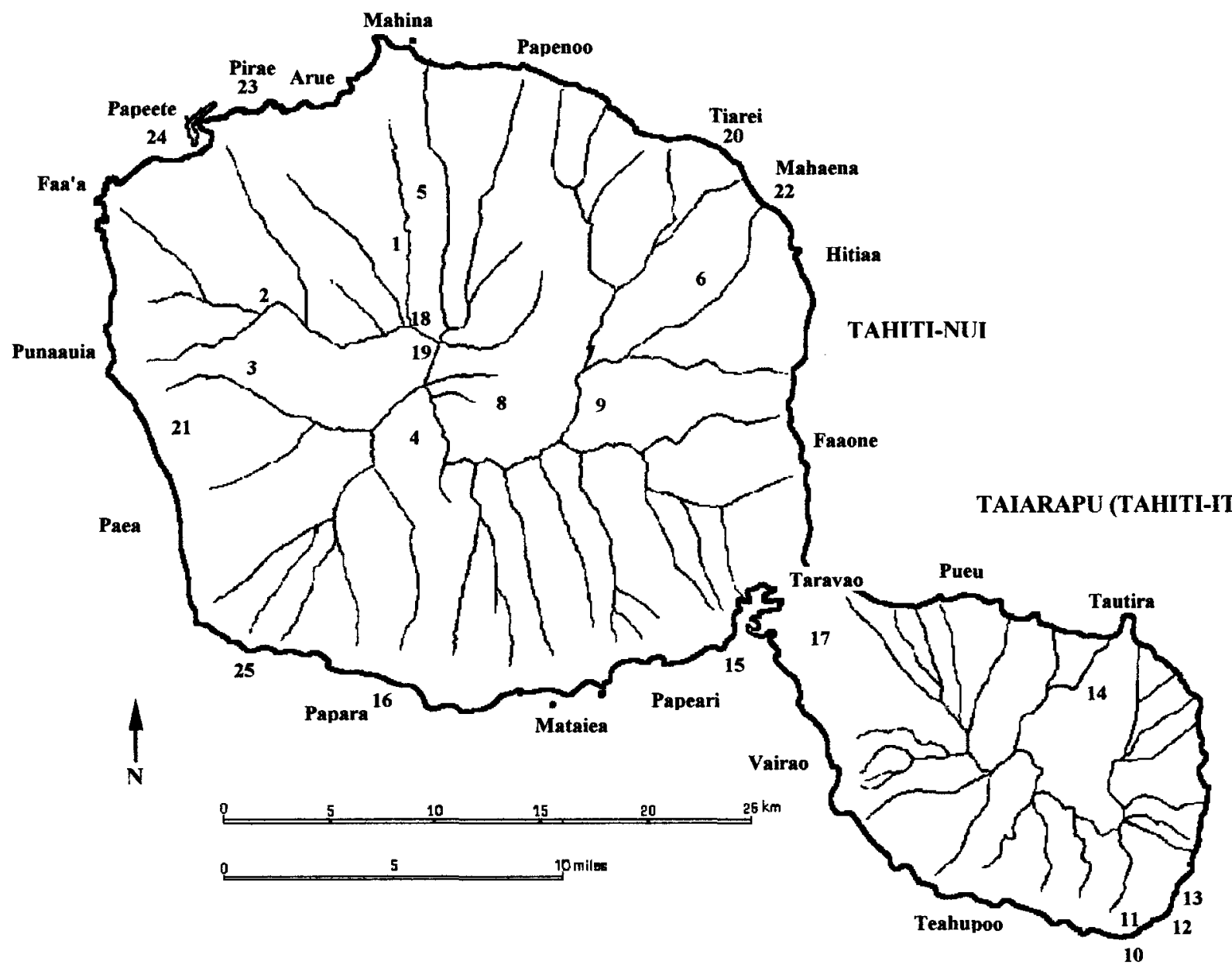

Fig. 1 Extant populations of partulids discovered on Tahiti since 1994 (includes administrative districts): 1, Taharaa crest (Mahina); 2 , Mt Marau (Faa'a); 3, Punaruu Valley (Punaauia); 4, Taharuu (Teihomono crest and above) (Papara); 5, Tuauru Valley (Mahina); 6 , Tahaute Valley (Mahaena); 7, Mt Mauru (Hitiaa); 8, Papeno'o caldera (Papeno'o); 9, Viriviriterai Plateau (Faaone); Te Pari area: 10, Fareara Point; 11, Faaroa Valley; 12, Baie de Taapeha; 13, Baie de Piarere; 14, Vaitehipa Valley. Introduction points: 15, Papeari; 16, Papara; 17, Taravao Plateau. Main peaks: 18, Mt Aorai; 19, Mt Orohena. Other: 20, Tiarei; 21, Papehue Valley; 22, Mahaena; 23, Pirae; 24, Papeete; 25, Tereehia Valley (E. Loeve). 


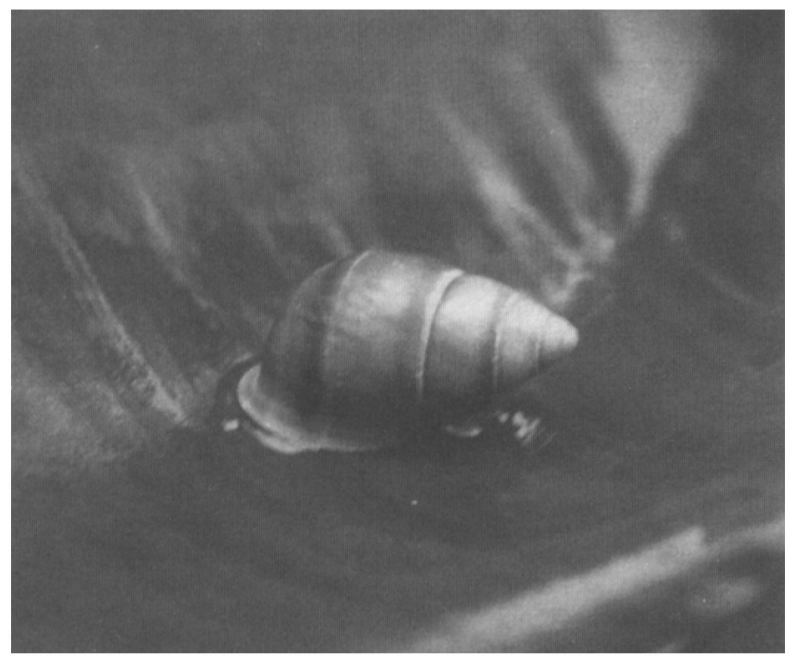

Plate 1 Partula otaheitana on decaying banana leaf, Mt Marau (D. Clarke).

the presence of live E. rosea (Pearce-Kelly et al., 1995), confirming an earlier sighting earlier that year (B. Clarke, pers. comm.).

In 1995, thriving populations of partulids were uncovered in Faaroa Valley, in south-east Tahiti-Iti, and some individuals in Tahaute Valley, below Mt Mauru on Tahiti-Nui. These unexpected discoveries suggested the possibility of other extant populations, and additional surveys on Tahiti were included in the itinerary of the 1995 expedition to the Society and Marquesas Islands (Pearce-Kelly et al., 1994).

Spreading at an estimated rate of $1.2 \mathrm{~km} /$ year, E. rosea had traversed the island of Moorea and apparently extirpated every species of Partula inside 10 years (Clarke et al., 1984; Murray et al., 1988). The experience of those researchers working on Moorea suggested that it was only a matter of time before E. rosea eliminated any surviving populations. The surveys of 1995, as recommended in the 1994 Action Plan (Pearce-Kelly et al., 1994), were therefore primarily seen as a rescue mission, with snails being collected for an expanded captive-breeding programme in Europe and, particularly, in the USA, where most of the collection went. Subsequent partulid finds in other localities have been discoveries, often incidental to other work, rather than organized surveys (see Table 1).

\section{Methods and results}

The fieldwork action plan for 1995 included a list of seven valleys that seemed the most promising sites for finding remaining populations of each of the 10 Tahitian partulid taxa identified (Plate 2). Those locations selected were accessible by road or track, and were areas where reserves might be constructed in the event of finding surviving populations. However, on arrival in French Polynesia, PILSG received further information from E.L. who, until then, was unknown to the group. The priority aims were consequently changed, and areas then known to contain populations of Partula were targeted for survey and collection.

A data sheet was prepared, based on that drawn up by B. Clarke and J. Murray for their original collections, and used in the 1991 survey of the Society Islands. This sheet provided a standard format for entering data, not only of the number and description of any snails collected and their location and host plant, but also of the size, shape, elevation and slope of the collecting area. A table was also included to record details of the dominant plants, shrubs and trees at the different levels, thus providing a general idea of the habitat of any

Plate 2 Typical Partula habitat containing climbing pandanus, Hibiscus tileaceus and fern (D. Clarke).

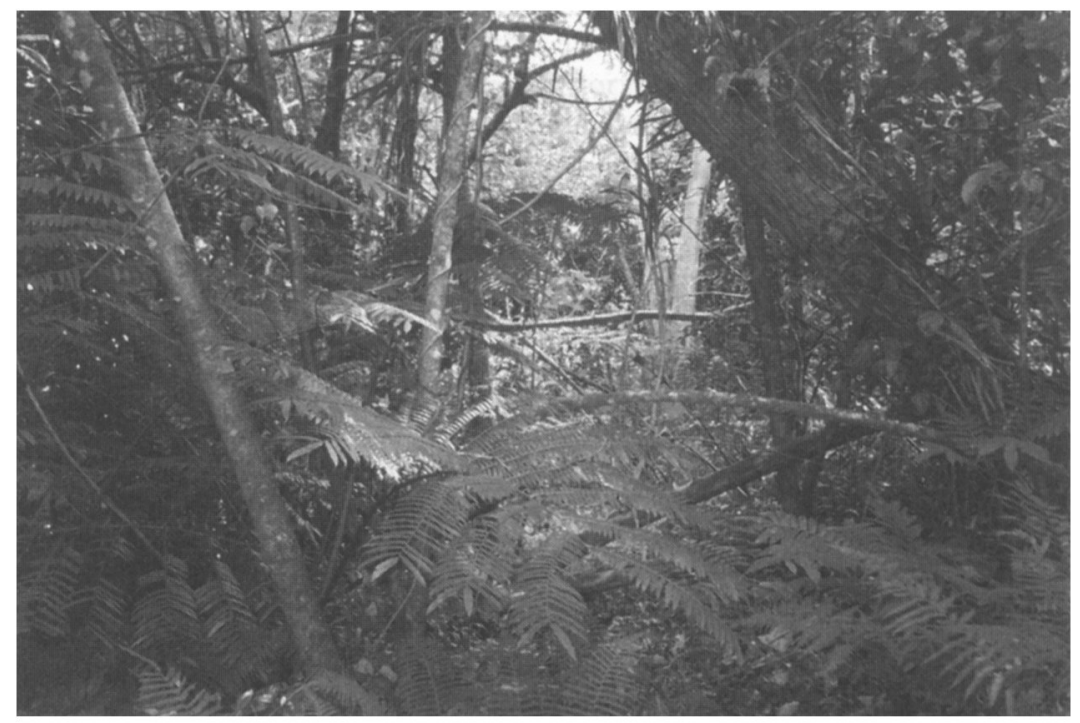


Table 1 Surveys on Tahiti 1995-97

\begin{tabular}{|c|c|c|c|}
\hline Location & $\begin{array}{l}\text { E. rosea } \\
\text { Present }(+) / \\
\text { Absent }(-)\end{array}$ & Species & No. collected \\
\hline \multicolumn{4}{|l|}{1995 PILSG expedition } \\
\hline \multicolumn{4}{|l|}{ Tahiti-Nui } \\
\hline \multirow[t]{2}{*}{ Tahaute Valley } & + & P. hyalina & 2 adults, 9 juveniles \\
\hline & + & S. attenuata (?) & 2 juveniles \\
\hline \multirow[t]{2}{*}{ Mt Marau $(1200-1400 \mathrm{~m})$} & + & P. otaheitana & 89 adults, 14 subadults, 51 juveniles \\
\hline & & Trochomorpha sp. & 12 adults \\
\hline \multicolumn{4}{|l|}{ Tahiti-Iti } \\
\hline Vaitehipa Valley & + & P. hyalina & 1 adult, 3 juveniles \\
\hline \multirow[t]{5}{*}{ South of Baie Piarere } & - & P. otaheitana & 45 adults, 36 juveniles \\
\hline & & P. hyalina & 11 adults, 2 juveniles \\
\hline & & P. clara & 50 adults, 22 juveniles \\
\hline & & P. affinis & 21 adults, 8 juveniles \\
\hline & & S. attenuata (?) & 3 juveniles \\
\hline \multirow{6}{*}{ Faaroa Valley } & - & Trochomorpha sp. & 15 adults \\
\hline & & P. otaheitana & 109 adults, 9 juveniles \\
\hline & & P. hyalina & 3 adults, 1 juvenile \\
\hline & & P. clara & 145 adults, 28 juveniles \\
\hline & & P. affinis & 84 adults, 16 juveniles \\
\hline & & S. attenuata (?) & 1 adult, 1 juvenile \\
\hline \multirow{3}{*}{$\begin{array}{l}\text { Faaroa Valley/Baie de } \\
\text { Taapeha }\end{array}$} & - & Trochomorpha sp. & 7 adults \\
\hline & & P. clara & 17 adults, 4 juveniles \\
\hline & & P. affinis & 10 adults, 5 juveniles \\
\hline \multirow[t]{5}{*}{ Fareara Point } & - & Trochomorpha sp. & 19 adults \\
\hline & & P. hyalina & 3 adults \\
\hline & & P. clara & 25 adults, 10 juveniles \\
\hline & & P. affinis & 17 adults, 2 juveniles \\
\hline & & Trochomorpha sp. & 5 adults \\
\hline 1996 & & & Comments \\
\hline Mt Marau $(990-1100 \mathrm{~m})$ & - & S. attenuata (?) & $\begin{array}{l}\text { Small populations by side of Faa'a road, on two } \\
\text { endemic Tahititan trees: Coprosma tahitensis (Rubiaceae) } \\
\text { and Glochidion tahitensis (Euphorbiaceae), and on Society } \\
\text { Island endemic, Weinmannia parviflora (Cunoniaceae) }\end{array}$ \\
\hline Mt Marau (1200 m) & - & P. otaheitana & $\begin{array}{l}\text { Similar densities to } 1995 \text { when collected. Mainly on ferns } \\
\text { and banana, but also on endemic species close to road. } \\
\text { Ten S. attenuata (?) collected for captive breeding }\end{array}$ \\
\hline $\begin{array}{l}\text { Papeno'o, Tuauru and } \\
\text { Punaruu Valleys }\end{array}$ & + & $\begin{array}{l}\text { Partula sp., yet to be } \\
\text { positively identified }\end{array}$ & Single or very few individuals seen \\
\hline \multicolumn{4}{|l|}{1997} \\
\hline Mt Orohena (950 m) & $?$ & S. attenuata (?) & $\begin{array}{l}\text { Single individual found on trail from Tuauru Valley } \\
\text { (Mahina District) }\end{array}$ \\
\hline Mt Mauru & $?$ & Partula sp., unidentified & $\begin{array}{l}\text { On crest starting from Faatautia Valley (Hitiaa District). } \\
\text { Small population }\end{array}$ \\
\hline $\begin{array}{l}\text { Taharuu Valley, } \\
\text { Viriviriterai Plateau }\end{array}$ & $?$ & Partula sp., yet to be identified & Populations recently seen. Ongoing surveys \\
\hline
\end{tabular}

surviving populations. The surveys on Tahiti took place during the second half of July, during the slightly drier, cooler season in French Polynesia. Each survey, except that on Tahiti-Iti, which involved a 4-day hike, was restricted to a single day. Each sample was collected by at least two people.

A collecting strategy had been drawn up that would take account of relative levels of population success, although this strategy had to adapt to circumstances as they changed on the expedition. Where very few individuals could be found (fewer than 10 individuals), one or two would be removed for identification. If 10-20 individuals were found, then six would be taken to try and begin a captive lineage, though ideally 10 is the minimum desirable number to found a captive population (Pearce-Kelly et al., 1994). If E. rosea was present in numbers, then all Partula seen would be removed. If a large, thriving population was to be 
found, then proportionately larger numbers of snails would be collected for the captive-breeding programme. In the case of Te Pari, population sizes ran into hundreds and possibly greater than a thousand, although lack of time and changing circumstances precluded use of standard population assessment methods. Both Crampton (1916) and Johnson et al. (1993) observed that replenishment was rapid after substantial collecting programmes, and subsequent visits have confirmed that the Te Pari populations survive at densities similar to those observed in 1995.

\section{Persistent partulid populations on Tahiti}

The surveys of 1995, 1996 and 1997 found surviving populations of both Partula and Samoana in a few valleys. Sightings of solitary or a few tree snails in remote spots were also found, indicating that these may be the last survivors of populations (or indeed species) now close to extinction. The largest populations of Partula found to date that have not been impacted by $E$. rosea have been in the most remote part of the island, in valleys of the south-east corner of Tahiti-Iti, close to the rugged coastal area known as Te Pari ('the cliffs'). The closest of the three introduction sites of E. rosea was on the Taravao Plateau on Tahiti-Iti (Fig. 1). Using a dispersal rate of $1.2 \mathrm{~km} /$ year, based on the Moorean experience (Clarke et al., 1984), it would be expected that $E$. rosea would have covered the $19 \mathrm{~km}$ to reach this part of the island, and eliminated the Partula populations sometime around 1991 or 1992, but this does not appear to have happened. Surveys are currently under way to establish the exact distribution of E. rosea on Tahiti-Iti.

One possible explanation is that the spread of E. rosea across the south-east peninsula of Tahiti has been delayed by the tracts of arable and plantation land that dominate large areas between Taravao and Te Pari. This idea is reinforced by a similar situation on the Marquesan island of Hiva Oa, where in 1995 populations of two species were found, believed to be Samoana ganymedes and $S$. decussatula, existing in the absence of E. rosea in Puamau Valley in an area surrounded by grazing land (Pearce-Kelly et al., 1995; $E$. rosea appeared to have eradicated all Samoana species from the remainder of the island until an individual was found on Mt Feani later in August).

The spread of $E$. rosea across Tahiti-Nui is more enigmatic. In 1984, it had invaded an area spanning the three introduction points, and $8 \mathrm{~km}$ inland. However, by 1987 the occupied area apparently extended to Pirae Valley in the north-west, some $23 \mathrm{~km}$ from the nearest recorded introduction point at Papara (Johnson et al., 1988). It is likely that there have been further un- recorded introductions of $E$. rosea, maybe close to the capital Papeete, or elsewhere in the more urbanized north-west of the island. Our experience in the Marquesas Islands is that farmers make such introductions (1995 PILSG unpublished data). It is also possible that introductions had taken place before the official releases, although this is less likely because the first $E$. rosea introductions into the Society Islands occurred on Tahiti.

Although scattered partulid individuals have been found in a few valleys on Tahiti-Nui, the only sizeable extant populations survive at $1000-1400 \mathrm{~m}$ in montane wet forest off the road leading to the crest of $\mathrm{Mt}$ Marau in the west of the island. This population differs from that found on Tahiti-Iti in that it has somehow managed to survive the threat from $E$. rosea, in spite of evidence that the predatory snail has been there (Pearce-Kelly et al., 1995). The Mt Marau populations are $16 \mathrm{~km}$ north of one of the introduction points, Papara, about two-thirds of the way to Pirae, so it is not clear why they have remained intact. At a dispersal rate of $1.2 \mathrm{~km} /$ year these populations were expected to be eliminated sometime between 1988 and 1990 but, as noted, E. rosea had already reached Pirae by 1987 .

We were aware of three points concerning E. rosea on Mt Marau: (i) it is probably responsible for the elimination of endemic tree snail species on the southern windward side of the ridge, and below $950 \mathrm{~m}$, the lower limit of native cloud forest with nearly pristine native habitats; (ii) live individuals were found along the crest (c. $1400 \mathrm{~m}$ ) in both 1994 and 1995; (iii) empty shells of $E$. rosea were found within the live partulid populations in the same years. From these facts we concluded that these populations were under threat from E. rosea encroaching from the southern windward side and moving over the ridge to the populations below, and further threatened by E. rosea moving up from plantation territory below. The 1995 PILSG expedition report stated that the Mt Marau populations are 'probably in imminent danger of extinction' (PILSG, unpublished data).

However, follow-up visits to the same areas in May 1996, and again in November 1996, could find no evidence of $E$. rosea, alive or dead, either on the crest or within the Partula populations, although these searches were not exhaustive. It is difficult to make any definitive judgments regarding the status of these populations, but $E$. rosea could cause their extinction in future. In addition, the endemic flora will soon be at serious risk from encroaching Miconia calvescens (Melastomataceae), an introduced South American plant species, which threatens the native forests, especially the montane forests where 70 per cent of the endemic plants are 
located. Miconia suppresses growth and regeneration of native plant species. It also affects native birds, insects and land snails by reducing their native habitats, food sources and breeding sites (Meyer \& Florence, 1996).

Little is known about the ecology or population dynamics of $E$. rosea. There is some evidence of an altitude ceiling for the species (Gerlach, 1994), possibly as a result of low temperatures. The temperature can fall to $7^{\circ} \mathrm{C}$ on the summit of Mt Aorai (J.-Y.M.), and below $10^{\circ} \mathrm{C}$ on Mt Marau $(1450 \mathrm{~m})$. It is noticeably cool in the cloud forests at high elevations. Partula, however, can evidently survive at these low temperatures, at least for short periods. Plainly, E. rosea reached the summit, but there is no direct evidence of it actively thriving there.

\section{Possible conservation measures}

The reasons for the persistence of the partulid populations on Tahiti are unknown. It is difficult to judge whether they are coexisting with $E$. rosea, are about to become extinct, or have survived the invasion and are continuing to persist. The situation differs between $\mathrm{Mt}$ Marau, where E. rosea has reached, and Te Pari, where it has yet to arrive. However, it is almost impossible to prevent the spread of E. rosea.

It would be ideal to protect the Tahiti-Iti populations in situ, but difficulty of access would impose a serious obstacle to the creation of a barrier similar to that of the exclosure constructed on Moorea (Pearce-Kelly et al., 1994). It is hoped that areas such as Mt Marau and Te Pari can be declared protected natural reserves because they are precious remnants of native Polynesian flora and fauna. However, protection alone would not be sufficient unless some barrier to the movement of $E$. rosea exists.

Further research into the biology of E. rosea, and particularly its population dynamics, needs to be carried out. There are no known natural predators, so a speciesspecific toxin in a snail bait, as tested in Hawaii (M. G. Hadfield, pers. comm.), could be a promising approach. This research is a vital component in the effort to conserve snail species endemic to the high islands of the Pacific.

In addition, the SDR (Service du Development Rural), formerly employed in agricultural research, has developed a greater concern about the conservation of native areas and the protection of native species (Y. Vernaudon, chief of the SDR, pers. comm.). Information and education of the public and the local authorities about the danger of introducing alien species has been increasing over the last 5-10 years, mainly due to the Miconia Research Programme. In May 1996, the entire family Partulidae was proposed for protection under the new regulation text on Nature Protection adopted in
December 1995 by the Assembly of French Polynesia (J.-Y. Meyer, pers. comm.). This legislation protecting Partulidae, and controlling the spread of E. rosea, was made law in 1997. A good relationship between the PILSG and the French Polynesian government authorities has developed, and joint initiatives for conservation and research are being planned.

The current distribution of partulid snails on Tahiti (Fig. 1) is an unfortunate testimony to the shortsightedness of a biological control measure implemented despite disastrous field trials in Hawaii, and in the face of scientific advice suggesting that the introduction would be catastrophic for native species of land snails. Their distribution is now limited to small remnant populations and a few scattered individuals. The extent of the problem is highlighted when comparisons are made with Crampton's (1916) distribution map (Fig. 2). During their work in French Polynesia from 1962 onwards, J. Murray (University of Virginia) and B. Clarke (University of Nottingham) confirmed Crampton's findings in general, but with certain taxonomic complications.

It appears, then, that although there are isolated populations of partulid snails on Tahiti, the southeastern coast of Tahiti-Iti appears to be the only major area still containing populations without encroachment by E. rosea. A realistic prediction is the extinction of wild Partula on the island within the next 10 years, though Samoana species may persist for longer as a result of their more peripheral habitat on the higher ridges. The control of $E$. rosea and a scientifically based reintroduction plan from the vital captive-breeding programme would be the primary objectives thereafter.

\section{Acknowledgements}

We thank Paul Pearce-Kelly, Sara Goodacre, Helen West, Richard Lewis, Jim Murray, Warren Spencer and Jonathon Cracknell for their hard work in the field, and Hélène Desmeroux for her valuable voluntary contribution. In addition, we are grateful to Bryan Clarke, Jim Murray again and Mike Bruford for their expert comments and suggestions, and to Terry Dennett for the photographs. As ever, we must thank the people of the Society Islands and the French Polynesian government departments involved in Partula conservation. Research was sponsored primarily by the Zoological Society of London, Fauna \& Flora International and the Natural Environment Research Council.

\section{References}

Clarke, B.C., Murray, J. \& Johnson, M.S. (1984) The extinction of endemic species by a program of biological control. Pacific Science, 38(2), 97-104. 


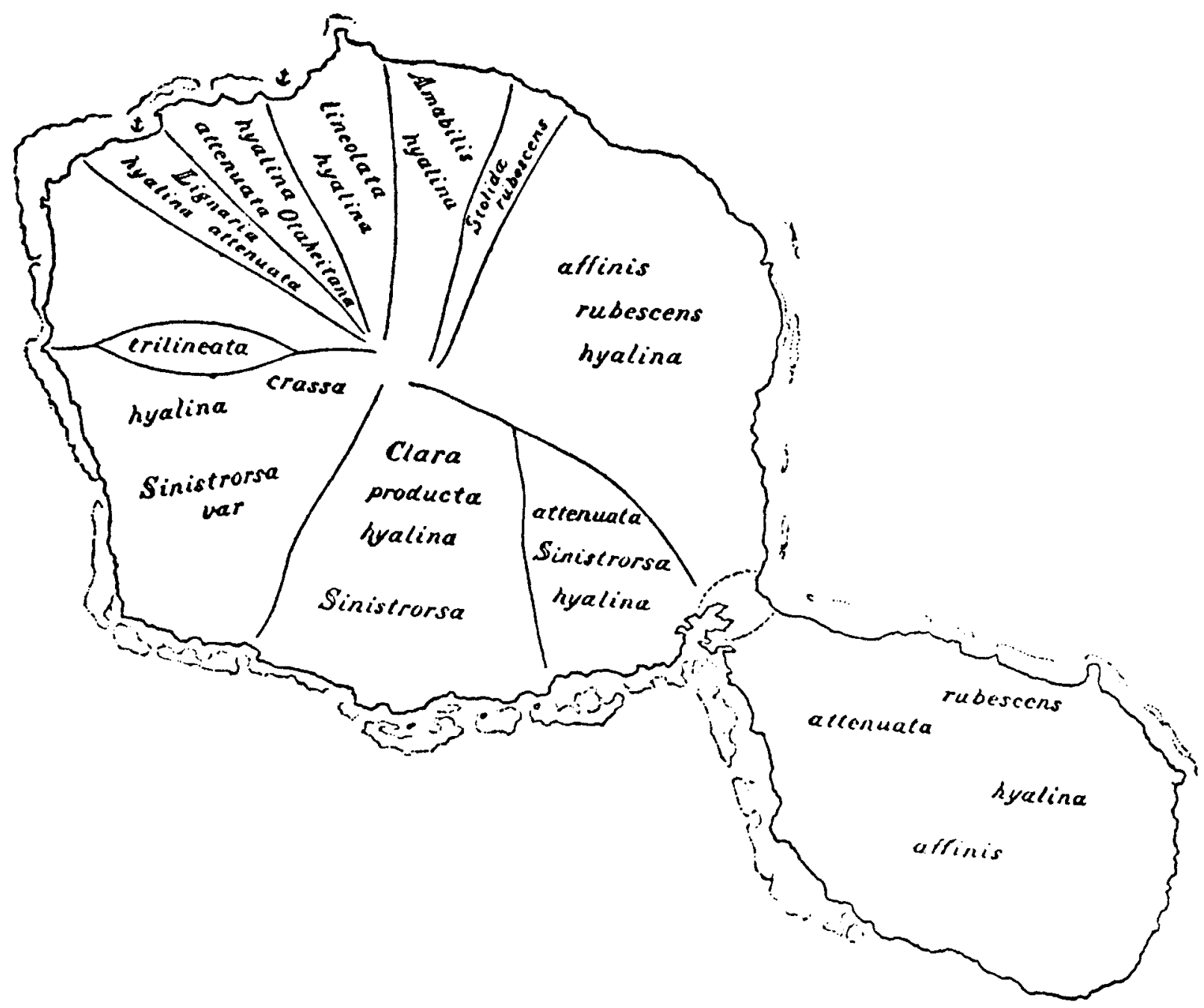

Fig. 2 Distribution of Tahitian Partulae (from Crampton, 1916).

Cowie, R.H. (1992) Evolution and extinction of Partulidae, endemic Pacific island land snails. Philosophical Transactions of the Royal Society of London B, 335, 167-191.

Crampton, H.E. (1916) Studies on the variation, distribution and evolution of the genus Partula. The species inhabiting Tahiti. Carnegie Institute Washington Publications, 228, 1-311.

Crampton, H.E. (1932) Studies on the variation, distribution, and evolution of the genus Partula. The species inhabiting Moorea. Carnegie Institute Washington Publications, 410, 1-335.

Garrett, A. (1884) The terrestrial mollusca inhabiting the Society Islands. Journal of the Academy of Natural Sciences Philadelphia (Series 2), 9, 17-114.

Gerlach, J. (1994) The ecology of the carnivorous snail, E. rosea. DPhil thesis, Oxford University.

Gould, S.J. (1991) Unenchanted evening. Natural History, $100(5), 7-14$

Hartman, W.D. (1881) Observations on the species of the genus Partula Fér., with a bibliographical catalogue of all the species. Bulletin of the Museum of Comparative Zoology Harvard College, 9, 171-190.
Johnson, M.S., Murray, J. \& Clarke, B.C. (1988) High genetic similarities and low heterozygosities in land snails of the genus Samoana from the Society Islands. Malacologia, 27, 97-106.

Johnson, M.S., Murray, J. \& Clarke, B.C. (1993) The ecological genetics and adaptive radiation of Partula on Moorea. In Oxford Studies in Evolutionary Biology (eds R. Dawkins and M. Ridley), pp. 167-238. Oxford Univerity Press, Oxford.

Kondo, Y. (1968) Partulidae: preview of anatomical revision. The Nautilus, 81(3), 73-82.

Mayer, A.G. (1902) Some species of Partula from Tahiti. A study in variation. Memoirs of the Museum of Comparative Zoology Harvard College, 26, 117-135.

Meyer, J.-Y. \& Florence, J. (1996) Tahiti native flora endangered by Miconia calvescens DC (Melastomataceae). Journal of Biogeography, 23(6), 775-781.

Murray, J., Murray, E., Johnson, M.S. \& Clarke, B.C. (1988) The extinction of Partula on Moorea. Pacific Science, 42(3-4), 150-153.

Pearce-Kelly, P., Clarke, D. \& Mace, G. (1994) Partula '94: An Action Plan for the Conservation of the Family Partulidae, 
by the Pacific Island Land Snail Group. Unpublished report, Zoological Society of London, Regents Park, London, NW 1 .

Pearce-Kelly, P., Clarke, D. \& Mace, G. (1995) Proceedings of the Annual Meeting of the Pacific Island Land Snail Group. Unpublished report, Zoological Society of London, Regents Park, London, NW1.

Pointier, J.-P. \& Blanc, C. (1985) Achatina fulica en Polynésie Française. Malakologische Abhandlungen, 1(11), 1-15.

\section{Biographical sketches}

Trevor Coote is a population geneticist at the Institute of Zoology who has travelled on a number of occasions to French Polynesia, where he has been involved in in situ conservation and field surveys. His principal interests are in the evolution and biogeography of Pacific Island invertebrates. This paper forms a chapter in his $\mathrm{PhD}$ thesis on the genetics and conservation of Polynesian tree snails (Family Partulidae) (University of London) to be submitted in March 1999.

Dave Clarke is Head Keeper at the Web of Life biodiversity exhibit at London Zoo and Fellow of the Royal Entomological Society. He is a specialist in invertebrates, and has worked on the captive propagation and field conservation of this neglected group of animals for over 15 years. Projects at the Invertebrate Conservation Unit at London Zoo have included several reintroduction programmes for endangered species, the most significant of which is with Partula. He is international studbook keeper for the captive breeding of partulid snails.

Eric Loeve is a biologist living on Tahiti. He has been involved in a number of the PILSG field surveys on that island, and is still engaged in current fieldwork on behalf of the group. His main interest is in the protection of the natural heritage of French Polynesia, in particular the endemic species of plants and animals. His thesis for the Diplôme d'Etudes Approfondies (Academie de Montpellier) was on the ecology and biogeography of Polynesian land snails (Partula and Trochomorpha).

Jean-Yves Meyer is a plant ecologist working for the Délégation à la Recherche, a governmental agency. His research interests include invasive alien plant species control and the conservation of endemic plant and animal species. He is currently working on a recovery programme for rare, endemic plants endangered by the invasive plant, Miconia calvescens on Tahiti, and collaborating on a recovery programme for the endangered Tahitian fly-catcher. His PhD thesis (Universite de Montpellier, 1994) was on the invasion processes of Miconia calvescens in French Polynesia. 